\title{
THE PREHISTORIC CAVE ART AND ARCHAEOLOGY OF DUNBAR CAVE, MONTGOMERY COUNTY, TENNESSEE
}

\author{
Jan F. Simek ${ }^{*}$, Sarah A. Blankenship ${ }^{1}, A_{l a n}$ Cressler $^{2}$, Joseph C. Douglas ${ }^{3}$, Amy Wallace ${ }^{4}$, \\ Daniel Weinand ${ }^{1}$, AND Heather Welborn ${ }^{1}$
}

\begin{abstract}
Dunbar Cave in Montgomery County, Tennessee has been used by people in a great variety of ways. This paper reports on prehistoric uses of the cave, which were quite varied. The vestibule of the cave, which is today protected by a concrete slab installed during the cave's days as an historic tourist showplace, saw extensive and very long term occupation. Diagnostic artifacts span the period from Late Paleo-Indian (ca.10,000-years ago) to the Mississippian, and include Archaic (10,000 to 3,000-years ago) and Woodland (3,000-1,000-years ago) cultural materials. These include a paleoindian Beaver Lake Point, Kirk cluster points, Little River types, Ledbetter types, numerous straight-stemmed point types, Hamilton and Madison projectile points. Woodland period ceramics comprise various limestone tempered forms, all in low quantities, and cord-marked limestone tempered wares in the uppermost Woodland layers. Shell-tempered ceramics bear witness to a rich Mississippian presence at the top of the deposit. Given this chronological span, the Dunbar Cave sequence is as complete as any in eastern North America. However, problems with previous excavation strategies make much of the existing archaeological record difficult to interpret. We present a new series of radiocarbon age determinations that show both the great time depth of the vestibule deposits and the problems with their integrity. There was also extensive prehistoric use of Dunbar Cave's dark zone, including mineral extraction, and ritual interment of the dead. Most importantly, thirty-five petroglyphs and pictographs were made on the cave walls, most probably during the Mississippian period. These include geometric shapes, abstract compositions, and human figures including a mythological hero warrior known from other examples of Mississippian iconography. Dunbar may also have seen ritual visitation very early, i.e., during the Archaic period (ca. 5,000-years ago), entailing the placement of offerings in the cave's interior waters.
\end{abstract}

\section{INTRODUCTION}

Over the past twenty years, archaeologists from the University of Tennessee and elsewhere, along with devoted avocational cavers, have worked to expand our knowledge of prehistoric cave art in the Appalachian Plateau uplands of southeastern North America (Simek and Cressler, 2005). First identified by archaeologists in 1980 (Faulkner et al., 1984), this cave art represents a widespread, complex, and longstanding aspect of indigenous prehistoric culture, one with local origins and development and one intrinsically linked to the evolution of prehistoric southeastern religious iconography (Faulkner and Simek, 1996). Although we have now examined more than one thousand southeastern caves in hopes of finding prehistoric art, there are more than nine thousand caves in Tennessee alone, with thousands more in Alabama, Georgia, and the upper south (Simek, 2010). There is a great deal of survey work still before us, and there will certainly be more cave-art sites discovered in the future. In this paper we will discuss the fiftieth cave in the catalog, Dunbar Cave (40MT43) in Montgomery County, Tennessee (Fig. 1).

As far as we can determine, dark-zone cave art (that is, decoration in the areas of caves beyond the reach of external light) was actually known among a small group of cavers in the Southeast from the 1950's. Engravings that were thought by those cavers who saw them to be prehistoric were identified at the mouth of $12^{\text {th }}$ Unnamed Cave in Tennessee. The site remained unknown to archaeologists until Charles Faulkner of the University of Tennessee was taken there in the 1980s in conjunction with his work at Mud Glyph Cave (Faulkner, 1988). Mud Glyph Cave itself was discovered in 1979 when a recreational caver explored a narrow subterranean stream passage and saw images incised into the wet clay lining the stream banks (Faulkner et al., 1984; Faulkner, 1986). The caver alerted an archaeologist friend who told Faulkner about these images. Upon seeing the site, Faulkner quickly recognized that the art was prehistoric, and in 1980, he initiated a documentation project. Mud Glyph Cave art was seen as resembling that found on Mississippian period ceremonial objects, and therefore, linked to the wider

\footnotetext{
* Corresponding Author: jsimek@utk.edu

${ }^{1}$ Department of Anthropology, University of Tennessee, Knoxville, TN 37996-0720

${ }^{2}$ United States Geological Survey, Atlanta

${ }^{3}$ Volunteer State Community College, Gallatin, TN 37066

${ }^{4}$ Dunbar Cave State Natural Area, Clarksville, TN 37043
} 


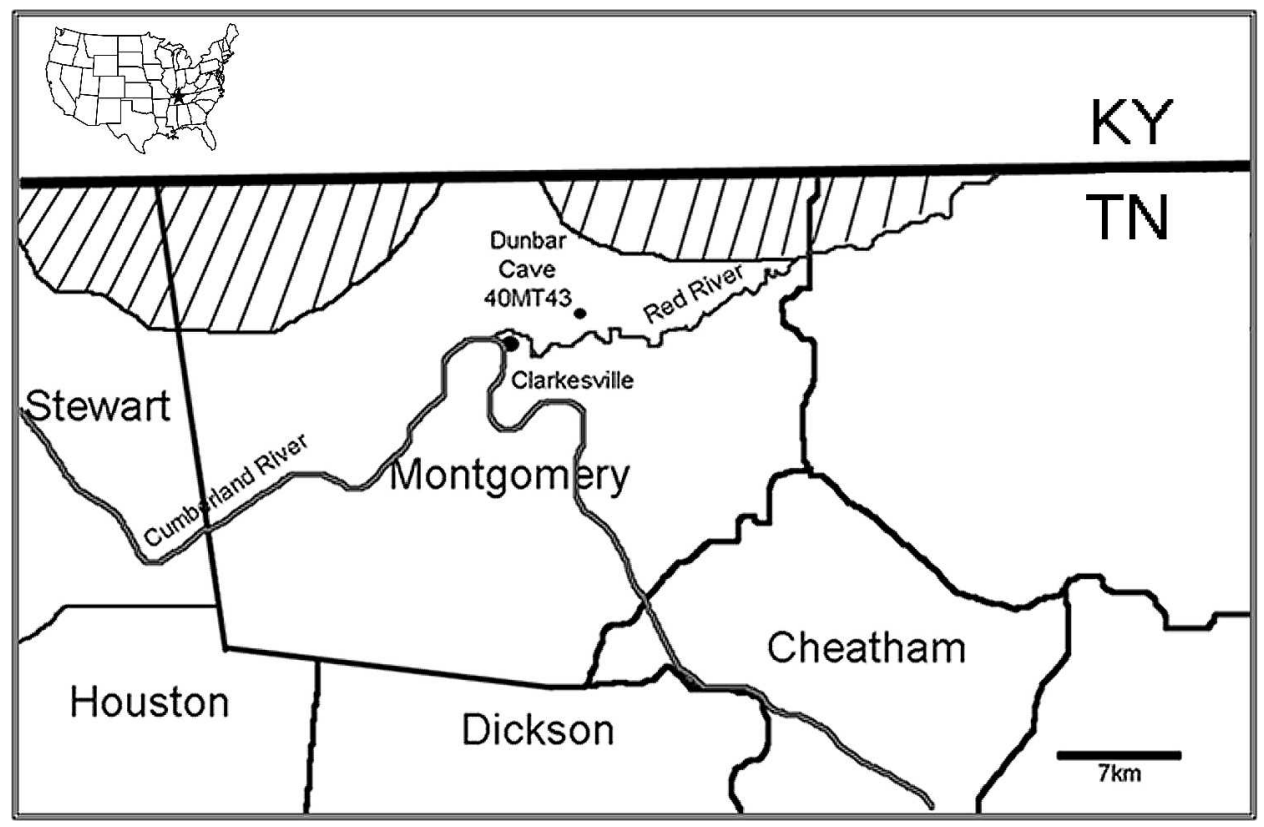

Figure 1. Map showing the location of Dunbar Cave, Tennessee.

Mississippian iconography, dating to after AD 1000 and labeled as the Southeast Ceremonial Complex (SECC) (Waring and Holder, 1945). Other sites quickly began to come to light. By 1988, Faulkner documented seven caveart sites, including Mud Glyph and $12^{\text {th }}$ Unnamed caves (Faulkner, 1988).

Since the discovery of Mud Glyph Cave, dark zone art has been recorded in sixty-nine other caves in Tennessee, Alabama, Florida, Georgia, Kentucky, Virginia, and West Virginia. There are also a few cave-art sites in the Mississippi Valley, including Arkansas (Sabo, 2008), Missouri (Diaz-Granados and Duncan, 2000; Diaz-Granados et al., 2001), Illinois (Wagner, 1996), and Wisconsin (Boszhardt, 2003). Chronological data from these sites demonstrate a long-term regional tradition of cave art beginning some 6000 years ago (Creswell, 2007; Simek and Cressler, 2009). As Faulkner observed, some of the imagery can be understood in terms of other prehistoric iconography, i.e., SECC, but some has less obvious connection with that imagery. As we show, the cave art in Dunbar Cave is markedly SECC in its content.

\section{The Prehistoric Cave Art of Dunbar Cave}

In January 2004 a caving group including Joseph Douglas (Professor of History at Volunteer Community College in Gallatin, Tennessee, and Adjunct in the Department of Anthropology at the University of Tennessee) and cave author Larry Matthews visited Dunbar Cave State Natural Area in the company of Amy Wallace, Interpretive Specialist at the park. In an area of the cave known as the Ballroom several hundred meters into the dark zone, Douglas noticed two charcoal drawings on the wall overlaid by nineteenth-century graffiti. (Places named in this paper can be located by reference to Walter Scheffrahn's 1978 map of Dunbar Cave based on a North Indiana Grotto survey as published in Matthews (2005, p. 27). The Ballroom, not labeled on that map, is the chamber just northeast of the Counterfeiters Room in the lower center). Douglas photographed what he saw and sent the photos to Simek at the University of Tennessee.

In February of 2005, Simek joined Douglas, John Froeschauer of the Tennessee Department of Environment and Conservation, Amy Wallace, and Alan Cressler of the U.S. Geological Survey at the site. On that visit, the two glyphs that had been discovered in January were observed and documented. In addition, a significant number of new pictographs and petroglyphs were identified in the same area of the cave and other passages. We also examined the cave floor for evidence of prehistoric occupation and found human remains in a small alcove near the cave mouth that had been noted as a looted burial area in earlier testing work by the Tennessee Division of Archaeology (Butler, 1977). We saw significant in situ deposits of burnt river cane (Arundinaria sp.) that were clearly ancient torch remnants, and stoke marks on the cave walls reflecting maintenance of burning torches.

Documentation has proceeded since 2005. This involves detailed photographic recording of the glyphs and mapping of the glyph distributions and the galleries in which the glyphs are found using a total-station laser transit. The survey continues in other parts of the cave, which is more than 8 miles long. Cane-torch stoke marks have been recorded at many places on the cave walls, both near and away from the glyph panels. In places where the sediment floor was not disturbed by historic digging, torch remnants 


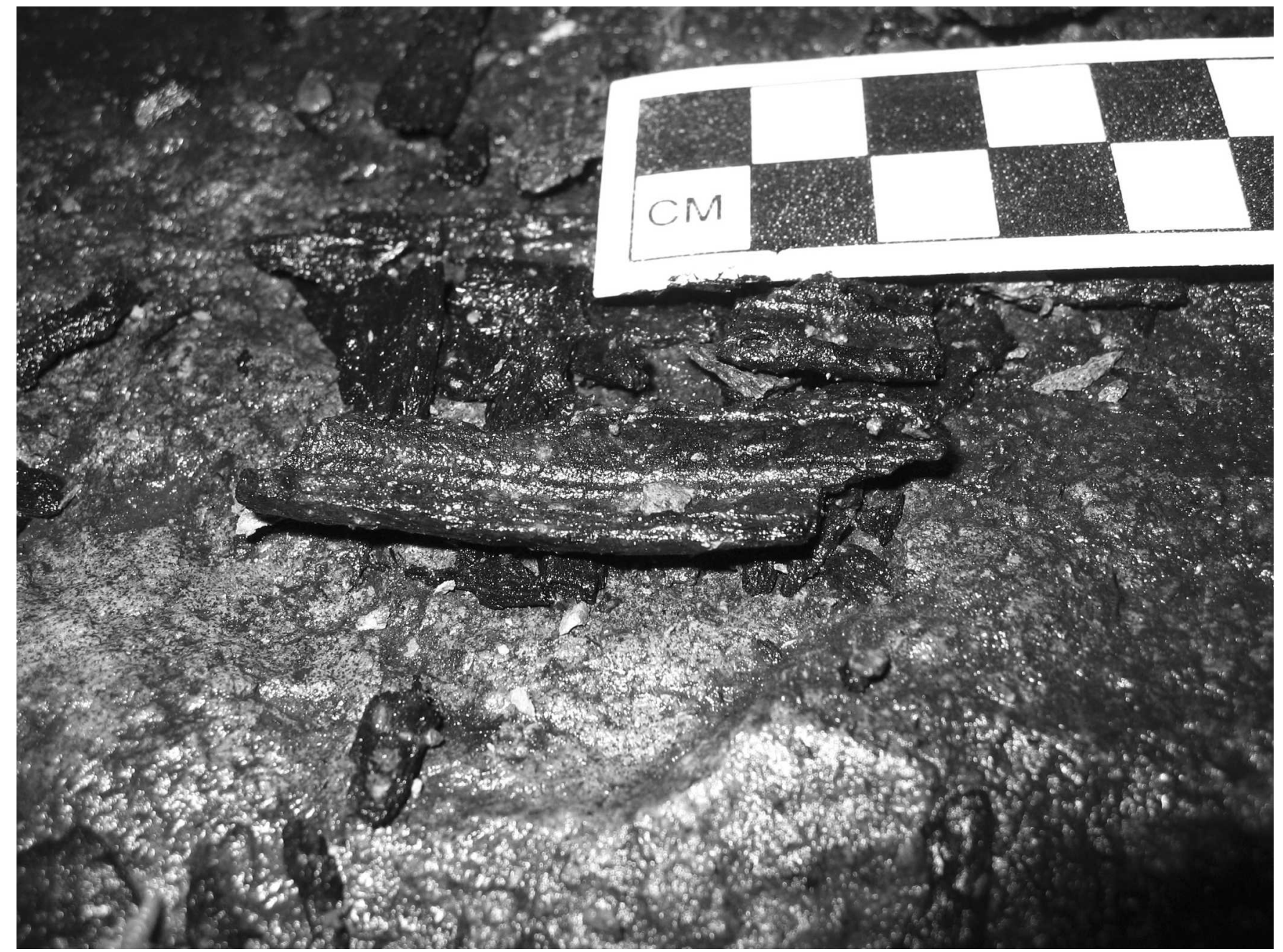

Figure 2. Burnt river cane (Arundinaria sp.) fragments on the sediment floor inside Dunbar Cave.

can be found (Fig. 2, Table 1). Several of these were taken as ${ }^{14} \mathrm{C}$ samples under terms of our state archaeological research permit.

A total of thirty-five individual glyphs have been recorded so far, nearly all concentrated in four panels along a west-side wall segment in the Ballroom. Two are pictographs of unidentifiable shapes incorporating disks. Three glyphs, two in the main room and one on the ceiling at the entrance to this room, are single circles. In each case, these are very faint images, and they may actually have

Table 1. Radiocarbon age determinations from Dunbar Cave (40MT43). All assays performed by Beta Analytic on burnt river cane (Arundinaria sp.) by Atomic Mass Spectrometry and calibrated at $2 \sigma$ with INTCAL04 (Reimer et al., 2004). Location descriptions in the table follow Walter Scheffrahn's 1978 map of Dunbar Cave based on a North Indiana Grotto survey (Matthews, 2005, p. 27).

\begin{tabular}{lccccc}
\hline $\begin{array}{l}\text { Sample } \\
\text { Reference }\end{array}$ & $\begin{array}{c}\text { Measured } \\
\text { Age BP }\end{array}$ & $\begin{array}{c}{ }^{13} \mathrm{C} /{ }^{12} \mathrm{C} \\
\text { Ratio }\end{array}$ & $\begin{array}{c}\text { Conventional } \\
\text { Age BP }\end{array}$ & Calibrated Date & Provenience \\
\hline Beta- 206332 & $2820 \pm 40$ & $-26.8 \%$ & $2790 \pm 40$ & 1020 to $830 \mathrm{BC}$ & $\begin{array}{c}\text { Collected near stoke marks between } \\
\text { Counterfeiters Room and Ballroom } \\
\text { Beta- 206333 }\end{array}$ \\
$680 \pm 40$ & $-27.2 \%$ & $640 \pm 40$ & AD 1280 to 1410 & $\begin{array}{c}\text { Collected from breakdown in entry } \\
\text { to Stone Mountain Room } \\
\text { Collected from floor of Ballroom at } \\
\text { base of wall between concentric circle } \\
\text { panel and warrior anthropomorph }\end{array}$ \\
\hline
\end{tabular}




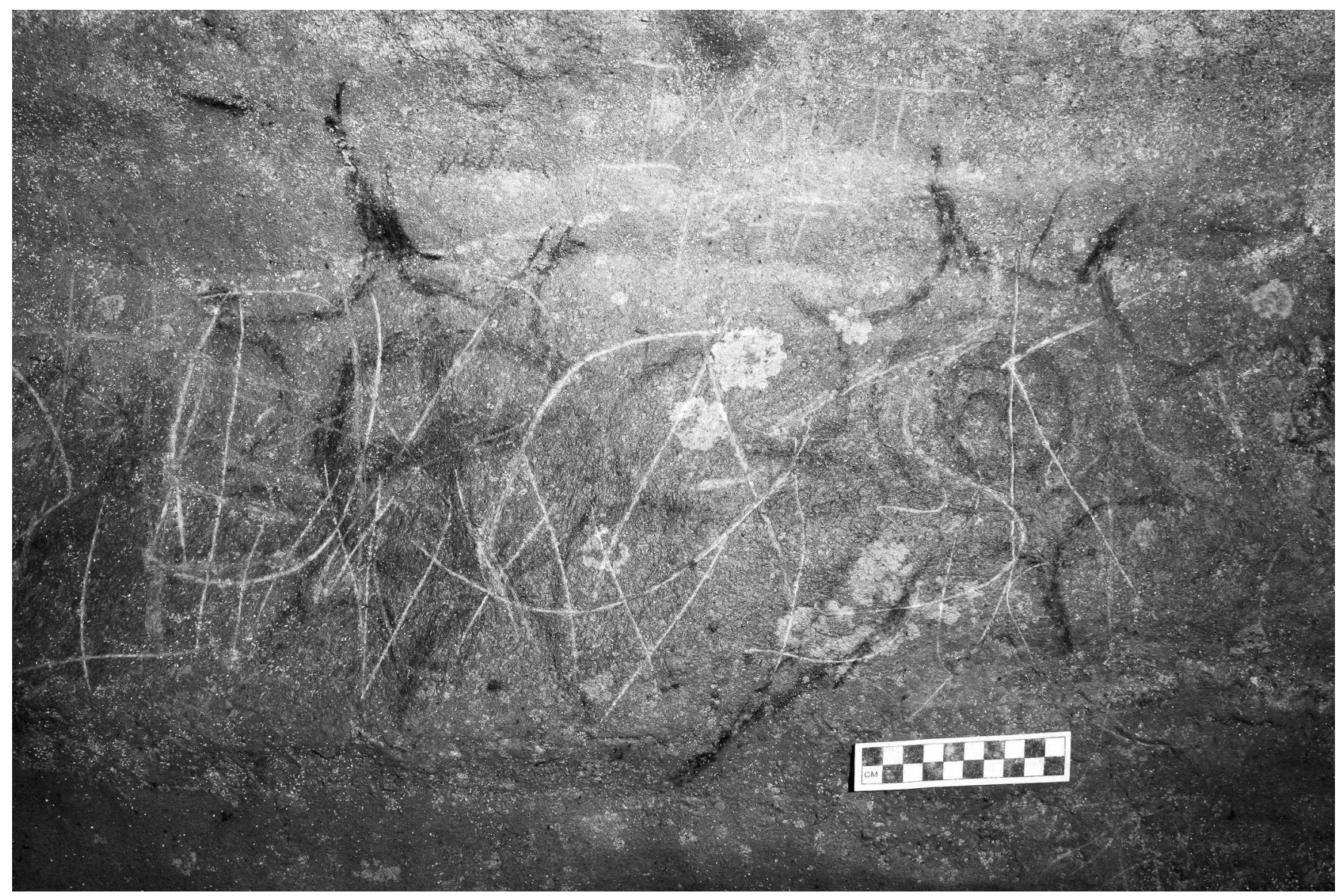

Figure 3. Circle glyphs from Dunbar Cave. These are complex images that include rayed circles and interior crosses. There are simple concentric circles as well in the glyph assemblage. Note " 1847 " scratched over the images. If this is a date engraved over the glyphs at that time, the glyphs must be older than the mid-nineteenth century.

been concentric rings that have faded beyond recognition. Nineteen individual glyphs are sets of concentric circles (Fig. 3). There is a great deal of variability in the number of circles involved in the concentric-circle images. Some images have only two rings, some have three nested together, and one complex image has four concentric circles of diminishing size. Concentric circles were produced using two techniques. Some images are drawn in black pigment (pictographs); others are engraved into the limestone of the cave wall (petroglyphs). In the main glyph gallery, seventeen of the circle glyphs are disposed in a single array of four vertical lines of images (Fig. 4). These lines include from two to six glyphs each, spaced about $25 \mathrm{~cm}$ apart. An arc was drawn passing over all the concentric circles in this panel, collecting them into a single composition. Circles, including concentric circles, are one of the most common design elements in prehistoric art in the southeastern US. They appear in ceramic designs and rock art outside caves, and they are also frequent in cave art assemblages. Circle motifs, however, while common during the Mississippian period, are not chronologically diagnostic in and of themselves; they can be found in art from a variety of prehistoric periods, early and late.
There are some circles in Dunbar Cave that do have chronological context, and those are the three cross-incircle images. One, located away from the main room, is a simple image drawn in black. Even this simple version has Mississippian connotations. The other two (see Fig. 3) are the first glyphs discovered and are more complicated than simple crosses in circles. Both are concentric circle images with exterior rayed circles and crosses of different forms inside their inner rings. Also note the 1847 date scratched over the black glyphs. The left image is a denticulate circle with a straight cross in the middle. The right image differs from its companion in having a tail on the outer denticulate circle and a left-facing swastika (Brain and Phillips, 1996, p. 7) in the center. Together, they form a remarkable pair of images. The denticulate cross is found frequently in Mississippian archaeological contexts. In particular, it is characteristic of a Mississippian-period gorget style named after the Cox Mound in northeastern Alabama where it was first identified (Holmes, 1883). This gorget type is most frequent in the Cumberland River area of Middle Tennessee, however, where it is combined with images of woodpeckers into a design referred to as the Cox Style by Brain and Phillips, who suggested that it was produced by 


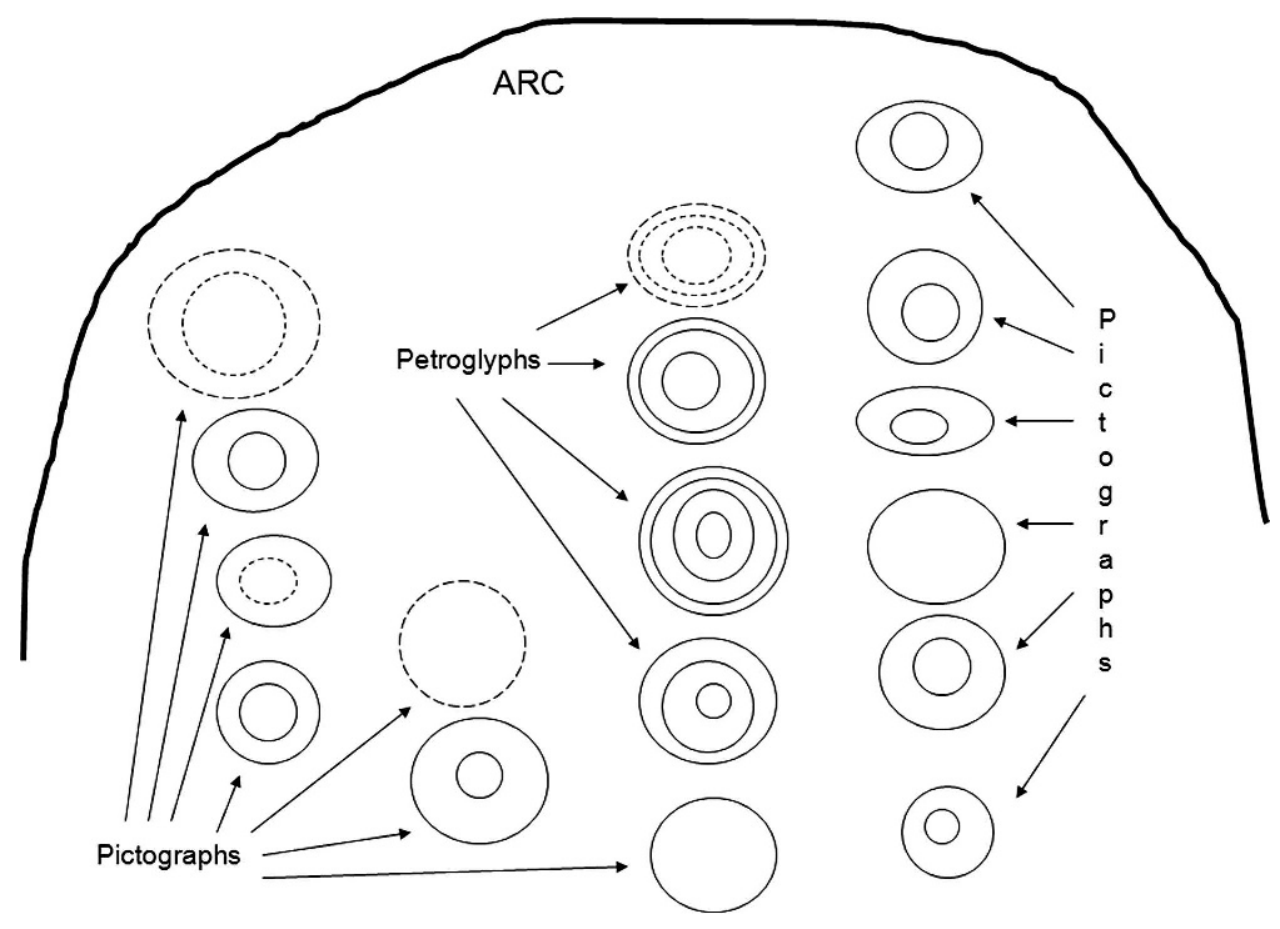

Figure 4. Sketch of concentric-circle array enclosed by a painted arc. Both pictographs and petroglyphs are included in the composition as indicated. Approximate size: $2 \mathrm{~m}$ wide $\times 1.5 \mathrm{~m}$ high.

craftspeople in the Cumberland region (Brain and Phillips, 1996). Dunbar Cave is within the Cumberland drainage, and the presence of these images here is strong evidence for a Mississippian origin.

The last two images, both complex anthropomorphs, also implicate Mississippian artists in the production of Dunbar Cave's artwork. One image that we originally recorded as a pair of abstract lines (Simek et al., 2007) has proved, on closer examination, to be the profile of a human face with fine features and long hair (Fig. 5). The second anthropomorph (Fig. 6a) is a reclining human-like form, clearly male, with well-defined arms and legs. Three fingers appear on the lower arm. The lower appendages (legs) thicken towards the feet, and those feet have claws, suggesting an animal element to the creature's makeup (Fig. 6b). The stippled head of this image is quite unusual. There is an axe or calumet above the head and a curving line extending out from the upper part of the head. The trunk below the arms is well defined and filled with pigment. The anthropomorph's waist and upper legs are covered with an hour-glass shaped garment, a kilt perhaps, which has several lines suggesting folds or decoration, but does not conceal the individual's phallus. All of these elements make perfect sense given what we know about prehistoric Mississippian iconography. That iconography focuses on the central tenets of Mississippian religion, namely warfare, death, and the ancestors (Hall, 1997; Muller, 1989). Mythical warriors were common and important characters in the religious narratives and thus in Mississippian art. They frequently combine human and animal characteristics, especially avian ones (Brown, 2007). These warriors are often shown with elaborate head decoration, including weapons in the hair and curling hair locks. Kilts are also common aspects of the warrior's regalia. The Dunbar Cave anthropomorph is readily interpreted as depicting a Mississippian cosmic warrior, which fits quite well chronologically with the denticulate circles discussed earlier. Interestingly, the head of this figure, which is the image in the Ballroom farthest from the cave mouth, points down-slope toward the river that flows through the cave's interior.

All of the pictographs in Dunbar Cave are black, suggesting that charcoal was used to produce them. However, we have observed in other sites that pigments were frequently applied as paints made by mixing a chromophore (coloring agent) with binders in a liquid form to enhance adhesion and permanence (Simek et al., 2010, p. 82). To investigate the pigment technology at Dunbar Cave, we sampled a few grains of pigment from one of the glyphs, along with a few more from a nearby cane-torch stoke mark. A control sample was also obtained from bare limestone near the sampled pictograph. This strategy was designed to determine whether the pigments used in Dunbar Cave had been applied with a simple charcoal pencil, such as the end of a cane torch, or more complex liquid paint preparations were applied. Using EDS/SEM analysis of composition, we found that the pictograph pigment (Fig. 7a) differs from the bare limestone control sample (Fig. 7b) in the elevated presence of carbon, indicating that the pictographs were produced using charcoal. No other 


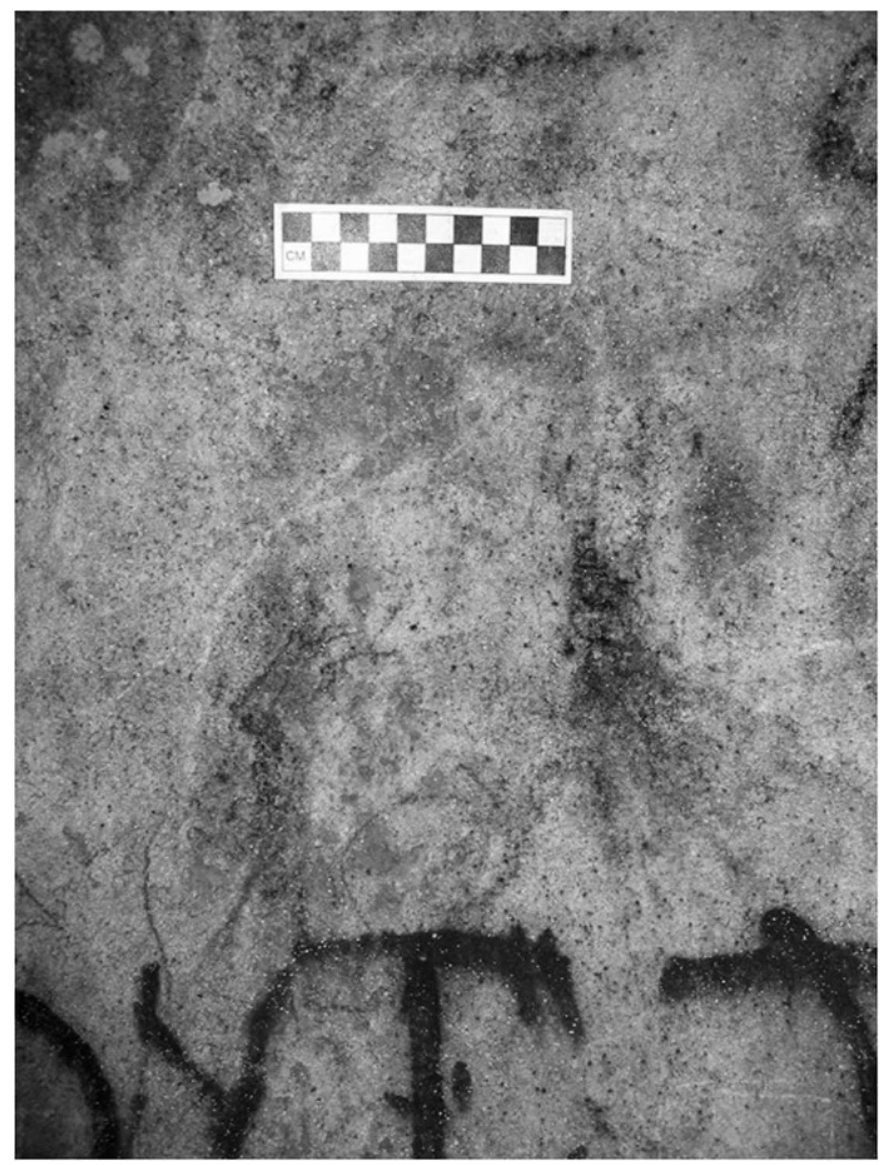

Figure 5. Pictograph of an anthropomorph head and face in profile.

differences were observed that might reflect inclusion of a paint binder. This suggests that the pictographs were produced using raw charcoal pencils. In fact, the pictograph sample was identical to the stoke mark in composition (Fig. 7c), signifying that burnt canes were probably used to produce the pictographs.

One of the most fundamental problems for students of parietal rock art (pictographs and petroglyphs located on walls) is chronology (Leroi-Gourhan, 1971). The pictures usually lack association with sediment deposits containing temporally diagnostic materials, whether artifacts of characteristic style or items that can be dated using radiometric techniques. Unfortunately, this is true for the Dunbar Cave pictographs. As we have seen, the pictographs are made of charcoal, which is subject to aging by radiocarbon assay, but a sample from one of the pictures (taken with great care not to damage the visual image) did not contain sufficient carbon to enable a reading, even by Accelerator Mass Spectrometry. We have obtained three AMS radiocarbon age determinations from inside Dunbar Cave, all from torch fragments recovered from the cave floor (Table 1). These samples were taken from various places inside the cave, and they elucidate the complex nature of prehistoric activity within the Dunbar Cave dark zone. One calibrated age determination (Beta206333) coincides perfectly with the time-period we would expect for the pictograph iconography: between AD 1200 and 1400. This sample was collected deep in the cave, however, the sample most distant from the glyphs. The sample closest to the glyphs, recovered directly below the circle panel (Beta 225002), has the most ancient calibrated age, about 4000 years before present, well within the Late Archaic period. The third determination (Beta206332), on a sample taken at the east edge of the Ballroom, is Woodland period, calibrated to around AD 900. Thus, while people were certainly inside the cave at the time suggested by the pictograph iconography, they were also there much earlier. In fact, this is something we find typical of caves used prehistorically in the Southeast (Simek, 2010; Simek and Cressler, 2001, 2005, 2009).

\section{7-78 Archaeological Work}

While the prehistoric cave art in Dunbar Cave is obviously of great anthropological interest, the archaeology of the site is also quite important. Dunbar Cave is presently owned and managed by the state of Tennessee, but that has not always been the case. Some accounts hold that the cave was mined for saltpeter in the mid-nineteenth century, and the nitrogen-rich sediment in the cave was also mined for fertilizer in the late nineteenth century. The cave then began a long history as a tourist attraction. Over time, the site was developed as a resort by several interests, including Roy Acuff after WW II, and it saw the installation of golf and swimming facilities, musical attractions befitting a site so close to Nashville, and a recreational lake (Van West, 1998; Whidby, 1999; Matthews, 2005). One effect of these rather specialized uses was the protection and eventual sealing of vestibule deposits at the mouth of the cave. First wooden and later concrete platforms were constructed on top of the sediments that filled the large rockshelter protecting the cave entrance (Butler, 1977). Thus, where so many of the great shelter sites in the eastern woodlands were looted for their artifacts, Dunbar Cave's archaeology remained intact for the most part. In 1973, the state acquired the site, and its protection was guaranteed.

When the state of Tennessee took possession of Dunbar Cave, test excavations were initiated both inside and outside the cave by the State Division of Archaeology (DOA) to determine the nature and extent of the site's archaeological record. DOA excavations were conducted on two separate occasions. Brian Butler directed a very small archaeological project in 1977 to determine whether intact archaeological deposits were present and how deeply they were buried beneath the fill (Butler, 1977). Three test pits were excavated at the entrance of the cave, after breaching the concrete dance-floor slab, and three additional pits were placed along the path just inside the cave. The three test pits outside the cave yielded charcoal, bone, shell, lithics, and pottery indicating human occupation. 

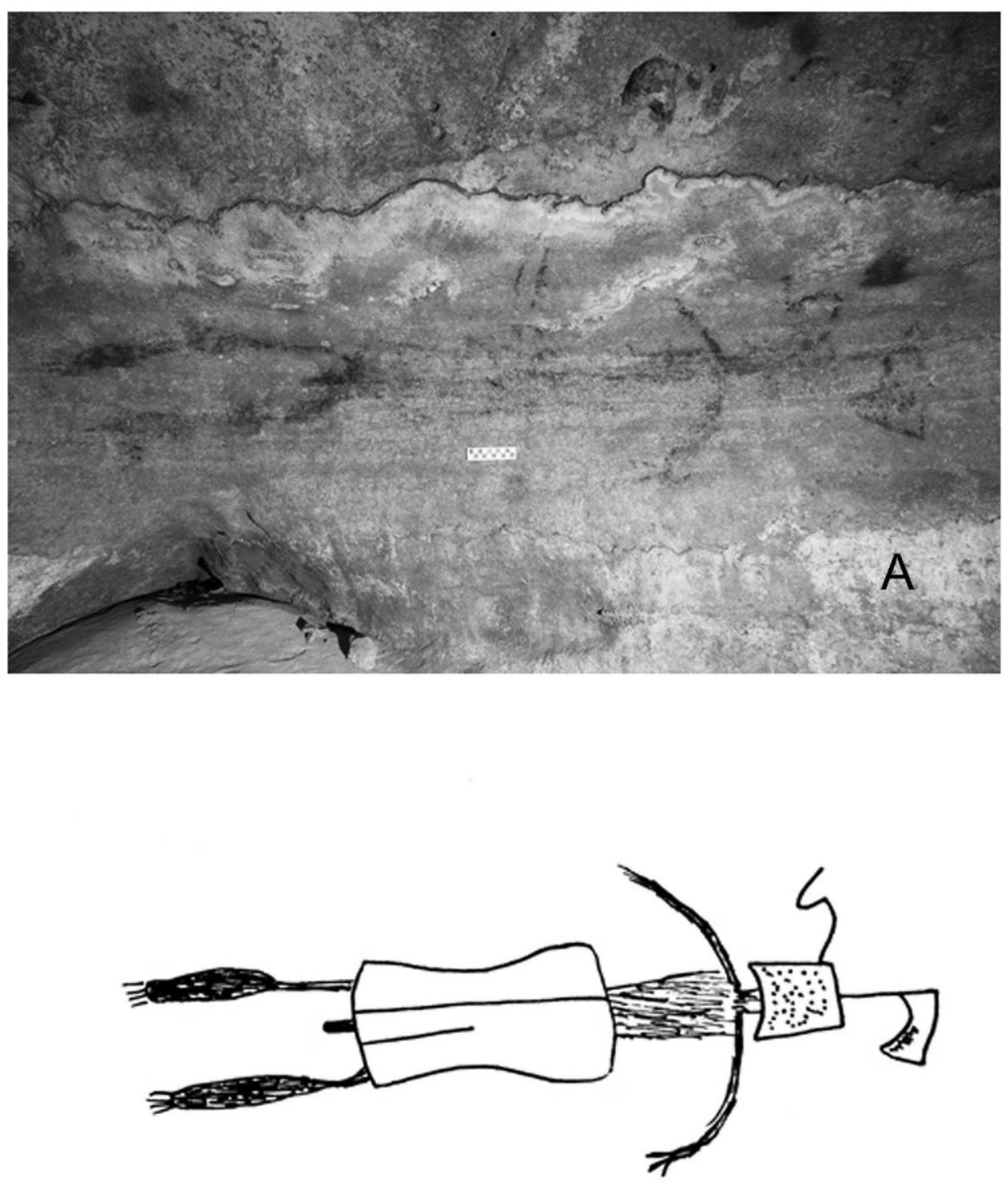

B

Figure 6. Pictograph of a reclining anthropomorph with animal features. A. Photograph of the pictograph. B. Sketch of the pictograph based on field observation using the red portion of the visible-light spectrum.

Those test pits within the cave interior exhibited only a minimal amount of cultural material.

In 1978, Robert Pace and Victor Hood led a larger, more involved archaeological excavation under the auspices of the DOA (Pace and Hood, 1978). For this investigation, the team dug a trench made up of eight $2 \times 2$ meter units running north-south at the mouth of the cave (Fig. 8). The units were excavated in arbitrary $10 \mathrm{~cm}$ levels starting from an established datum, with vertical control being maintained by a transit. The deposits were found to be more than $5.5 \mathrm{~m}$ (nearly $20 \mathrm{ft}$ ) deep in some areas, making this an extraordinary archaeological deposit with technical challenges for its excavators. More than sixty storage boxes of material were filled, a collection that presently resides at the University of Tennessee. Diagnostic artifacts span the period from Late Paleo-Indian (about 10,000 years ago) to the Mississippian (to AD 1500), and they include Archaic (10,000 to 3000 years ago) and Woodland (3000 to 1000 years ago) cultural materials. Lithic artifact types in rough sequence include a Beaver Lake Point, Kirk cluster points, Little River types, Ledbetter types, numerous straight-stemmed point types, and Hamilton and Madison projectile points. Woodland ceramics comprise various limestone-tempered forms, all in low quantities, and cord-marked limestone-tempered wares in the uppermost Woodland layers. Shell-tempered ceramics bear witness to a rich Mississippian presence at the top of the deposit. Given this chronological span, the Dunbar Cave sequence is as 

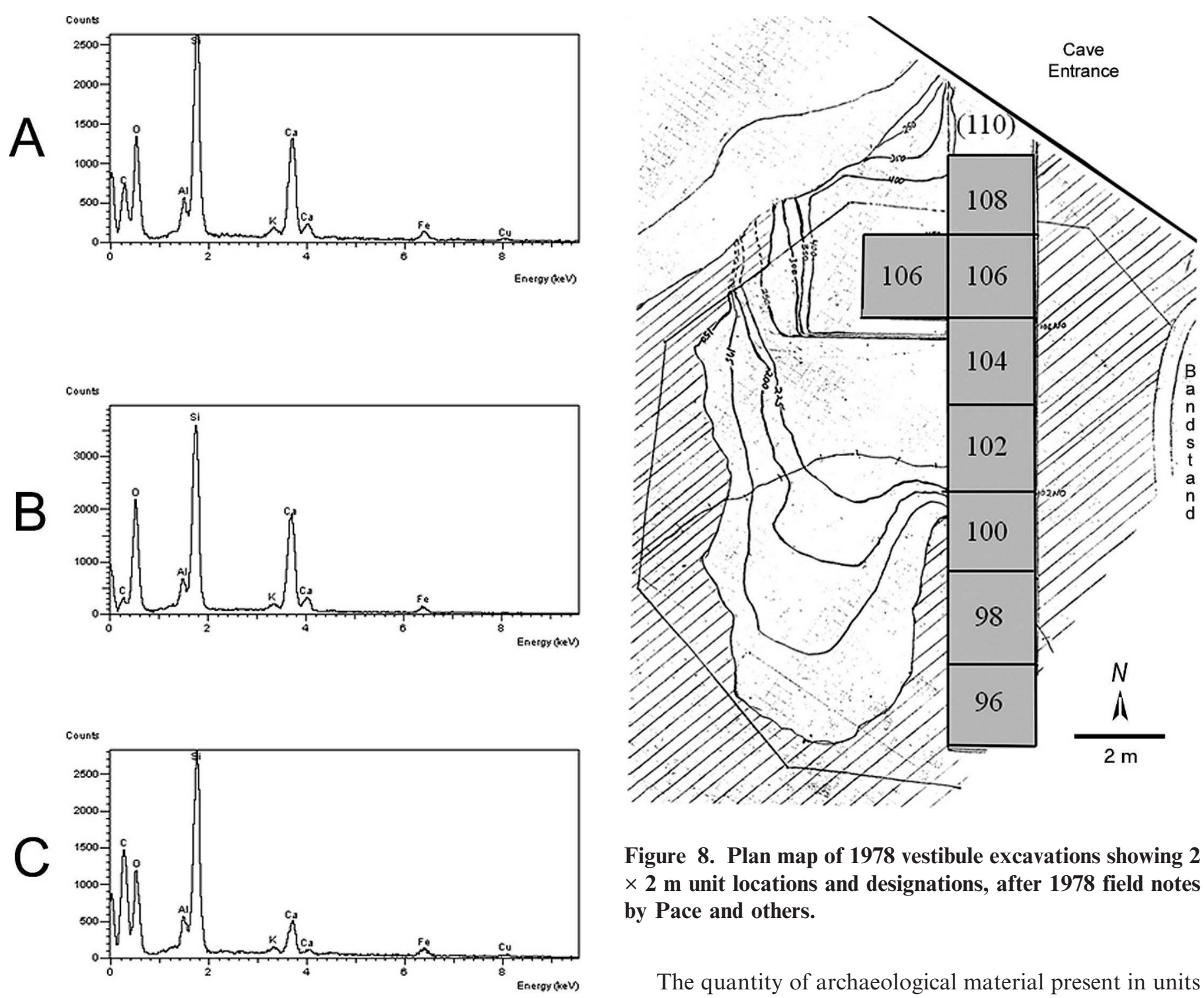

Figure 7. Element spectrographs showing results of EDS/ SEM analyses of material composition. A. Analysis of pictograph pigment. B. Analysis of bare limestone wall as a control. C. Analysis of cane-torch stoke mark.

complete as any in eastern North America (Pace and Hood, 1978). However, we do not discuss the artifacts in more detail here because, as noted below, there are general problems with provenience stemming from the complex stratigraphy of the site and the way it was excavated.

Units 96N0 through 106N0 (see Fig. 8) appear to have been excavated simultaneously, while the top levels of $108 \mathrm{~N} 0$ and 110N0 were stripped with a shovel after being identified as containing fill. Units were excavated to different depths. For example, Unit 96N0 was excavated to $2.65 \mathrm{~m}$ deep, where large boulders prevented any more excavation. Limestone breakdown prevented excavation deeper than $2.75 \mathrm{~m}$ in Unit 98N0. Unit 100N0 was excavated to a depth of $2.65 \mathrm{~m}$ and contained no diagnostic artifacts.

Figure 8. Plan map of 1978 vestibule excavations showing 2 $\times 2 \mathrm{~m}$ unit locations and designations, after 1978 field notes by Pace and others.

The quantity of archaeological material present in units $102 \mathrm{~N} 0$ through $106 \mathrm{~N} 0$ necessitated deeper excavations to document the prehistoric use of the cave in its entirety. Unit $102 \mathrm{~N} 0$ was excavated to a depth of $4.45 \mathrm{~m}$. Ceramics, lithics, and bone were recovered through the entire deposit. The artifact sequence in the square, however, is confusing. With regard to the pottery, many levels contain both limestone- and shell-tempered pottery. This is unusual because limestone pottery tends to be earlier, associated with the Woodland period, and shell temper is a later Mississippian characteristic (Lewis and Kneberg, 1995). Even more problematic are levels containing shell-tempered pottery that lie beneath levels identified as Archaic from diagnostic lithics. There would appear to be problems with the stratigraphy in this unit.

From Unit 104N0, only ten diagnostic artifacts were recovered. The unit was excavated to a depth of $3.35 \mathrm{~m}$. Shell-tempered shards were found in levels 2 and 4, conveniently above limestone-tempered shards that were recovered from levels $4,5,8$, and 17 . The only diagnostic lithics were two Late Archaic stemmed points from level 8, 
so this unit has probable Woodland pottery stratigraphically below Archaic projectile points. Again, stratigraphic problems are apparent.

Numerous artifacts were recovered from Unit 106N0. In the upper levels, sketches were made of the various deposits. This was to account for the lack of the sediment being screened because it was considered fill and discarded. Levels 2 through 5 were removed by shovel, as they were entirely composed of fill. Hand-excavation began only with level 15 at a depth of $2.95 \mathrm{~m}$, where there was no intrusion from the red-clay fill. Excavation continued to level 31, seeking the bottom of the cultural deposits. At around $5.2 \mathrm{~m}$, the decision was made to use a backhoe to facilitate digging. At $5.55 \mathrm{~m}$ (level 41), water began to impede the excavation. Vertical control was maintained for three more levels before it became impossible to understand the context of the artifacts. The problems with stratigraphic control observed for Unit $102 \mathrm{NO}$ are even more apparent when the rich assemblages from 106NO are examined. With regard to pottery, Mississippian and Woodland shards are routinely found together until level 29 (with a maximum depth of $4.45 \mathrm{~m}$ ). Two shell-tempered shards are found below this in level $38(5.25-5.35 \mathrm{~m})$.

Because the relationship between the archaeological levels defined during excavation and the temporally diagnostic artifact types is confused, we made an effort to resolve the confusion by securing ${ }^{14} \mathrm{C}$ age determinations from several 1978 excavation units. Table 2 shows the twelve dates obtained and the measurement and provenience data associated with the samples. All analyses were carried out at the University of Tennessee Radiocarbon Laboratory. The first four determinations were made on samples from Unit $102 \mathrm{NO}$. While partially conforming to what might be expected given depths below surface, the two upper dates are inverted, indicating stratigraphic mixing even at this fine scale of analysis. The second set of four determinations is from Unit 106NO. The first pair is inverted from stratigraphic expectations, while the second two, supposedly associated with bison remains, are older than their association would indicate. The last four ages are from Unit $106 \mathrm{~N} 2 \mathrm{~W}$. The first pair, in sequence within a single hearth feature (F11), is stratigraphically inverted, while the last two determinations are statistically identical even though they come from superimposed levels. Thus, new ${ }^{14} \mathrm{C}$ age determinations do not clarify the chronology. Instead, age inversion, inaccurate association, and lack of agreement between stratigraphic position and radiometric age characterize the Dunbar Cave vestibule excavation sequence.

Clearly, there are problems with the stratigraphy from the entire 1978 excavation. This might be due to one or both of two factors. It may be that the site is greatly disturbed and has lost stratigraphic integrity because of postdepositional processes affecting the sediments, something that is always possible in the complex, dynamic deposits that fill caves and rockshelters. Or, it may be that excavation strategies failed to establish accurate provenience for the artifacts recovered from the site. We believe that the latter problem explains observed incongruities in the Dunbar Cave artifacts.

After excavation at Dunbar was completed and the deep trench at $106 \mathrm{~N}$ expanded to two units wide to provide a profile, the drawing shown in Figure 9 was made of the deep sequence. There are complex but clear, perceptible stratigraphic layers and limits recorded by the artist. What is also apparent is that the archaeological layers are not flat and level; indeed they are mounded with sloping sides, as might be expected for a talus-slope deposit, and this character is amplified the deeper into the deposit one goes. Excavation strategy, however, was to bring all eight units to a single horizontal plane prior to excavation with absolute depth below the site datum determining the stratigraphic collection unit. According to the notebook, "Level 1 was designed to bring the entire trench to a uniform horizontal plane at the lowest point in the trench. ... all other levels were uniformly $10 \mathrm{~cm}$ in thickness." Thus, level 2 was defined as a ten-centimeter spit in each square between 1.65 and 1.75 centimeters below the surface. All levels had the same vertical depth regardless of unit or sedimentary context. In essence, the collection units were constant volumetrically but stratigraphically arbitrary. The effect of this was devastating for artifact provenience. Take, for example, a single collection spit in Unit $106 \mathrm{NO}$ where, according to the drawn profile, seventeen identifiable strata are mixed together into one horizontal $10 \mathrm{~cm}$ unit level (see Fig. 9). This example is replicated time and again across the trench. Thus, it is not surprising that artifacts from different time periods occur in nearly every level from every square. The bad news is that we cannot recover stratigraphic provenience for these materials. The good news is that the site itself probably has intact strata that can ultimately yield controlled data to new excavation.

There are some aspects of the 1978 collection that can still provide us with important information. Weinand, for example, has undertaken a study of the archaeofaunas from the 1978 Dunbar Cave excavations. The assemblage yields very few surprises. Species present include deer, small mammals, fish, turtles, and turkeys, all typical foodprey species found in southeastern archaeological sites. Two flying squirrels and a swan, more rare in archaeaofaunas, have also been identified. The majority of the Dunbar Cave bones from all levels, including the deepest, are burned, indicating a human role in their accumulation. Some are fashioned into tools (awls or punches), and butchery cut-marks are evident on some remains.

The bones of three particularly interesting species were found in units $108 \mathrm{~N}$ and $106 \mathrm{~N}$. One of them was identified in 1978 as one of the very few Bison bison bones ever identified in a Tennessee archaeological site. In fact, a total of three buffalo bones have now been identified, all from the same provenience. The bones include a metacarpal, first 
Table 2. Radiocarbon age determinations from vestibule excavations at Dunbar Cave (40MT43). Samples in each unit listed in deepening stratigraphic order. All assays performed by University of Tennessee Radiocarbon Laboratory using Liquid Scintillation Counting and calibrated at $2 \sigma$ with INTCAL04 (Reimer et al., 2004). Location descriptions in the table follow (Pace and Hood, 1978).

\begin{tabular}{|c|c|c|c|c|c|}
\hline $\begin{array}{l}\text { Sample } \\
\text { Reference }\end{array}$ & $\begin{array}{l}\text { Measured } \\
\text { Age BP }\end{array}$ & Calibrated Date & $\begin{array}{l}\text { Archaeological } \\
\text { Level }\end{array}$ & $\begin{array}{l}\text { Depth Below } \\
\text { Surface, } \mathrm{cm}\end{array}$ & Provenience \\
\hline \multicolumn{6}{|l|}{ Unit $102 \mathrm{NO}$} \\
\hline UT 08-051 & $3870 \pm 78$ & 2569 to $2064 \mathrm{BC}$ & 5 & 102 & $\begin{array}{l}\text { Single piece of charred wood } \\
\text { from general midden }\end{array}$ \\
\hline UT 08-050 & $3770 \pm 70$ & 2459 to $1984 \mathrm{BC}$ & 10 & 102.52 & $\begin{array}{l}\text { Possibly residual feature - no } \\
\text { depth - piece of antler in } \\
\text { association }\end{array}$ \\
\hline UT-08-048 & $5570 \pm 107$ & 4690 to $4174 \mathrm{BC}$ & 21 & 103.61 & $\begin{array}{l}\text { Concentrated scatter of } \\
\text { wood charcoal }\end{array}$ \\
\hline UT-08-043 & $6125 \pm 141$ & 5371 to $4718 \mathrm{BC}$ & 21 & 103.7 & $\begin{array}{l}\text { Charcoal scatter } \sim 10 \mathrm{~cm} \text { in } \\
\text { diameter } \mathrm{N} \text { half of central } \\
\text { portion }\end{array}$ \\
\hline \multicolumn{6}{|l|}{ Unit $106 \mathrm{NO}$} \\
\hline UT 06-034 & $4300 \pm 70$ & 3309 to $2668 \mathrm{BC}$ & F.5 S $1 / 2$ & 103.45 & $\begin{array}{l}\text { Charcoal in ashy layer } \\
\text { directly above Feature } 5 \text { - } \\
\text { west profile }\end{array}$ \\
\hline UT 06-031 & $3900 \pm 70$ & 2572 to $2151 \mathrm{BC}$ & F.5 S $1 / 2$ & 103.72 & $\begin{array}{l}\text { Wood charcoal directly below } \\
\text { fired clay cap of Feature } 5\end{array}$ \\
\hline UT 08-052 & $960 \pm 81$ & AD 897 to 1251 & $\cdots$ & $\cdots$ & $\begin{array}{l}\text { Charcoal in a (hearth?) as- } \\
\text { sociated with the Bison bone }\end{array}$ \\
\hline UT 08-052(2) & $1000 \pm 93$ & AD 782 to 1224 & $\cdots$ & $\cdots$ & $\begin{array}{l}\text { Charcoal in a (hearth?) as- } \\
\text { sociated with the Bison bone }\end{array}$ \\
\hline \multicolumn{6}{|l|}{ Unit $106 \mathrm{~N} 2 \mathrm{~W}$} \\
\hline UT 06-028 & $6740 \pm 70$ & 5752 to $5521 \mathrm{BC}$ & F.11 & $\cdots$ & $\begin{array}{l}\text { Charred wood Level IV, } \\
\text { Feature } 11\end{array}$ \\
\hline UT 08-053 & $6700 \pm 73$ & 5724 to $5490 \mathrm{BC}$ & F.11 & $\cdots$ & Charcoal W 1/2 F.11, Lev. 7 \\
\hline UT 08-026 & $6740 \pm 143$ & 5980 to $5386 \mathrm{BC}$ & 37 & $\cdots$ & $\begin{array}{l}\text { Wood charcoal gathered from } \\
\text { scatter throughout level }\end{array}$ \\
\hline UT 08-025 & $6790 \pm 109$ & 5966 to $5511 \mathrm{BC}$ & 42 & $\cdots$ & $\begin{array}{l}\text { Hand sorted charcoal from con- } \\
\text { centrated scatter in NE } 1 / 4\end{array}$ \\
\hline
\end{tabular}

identified in 1978, which shows clear affinity to bison rather than cattle (Fig. 10). In addition, both a first and a second phalanx articulate with the metacarpal: MNI is therefore 1. No cut marks are present to show that Dunbar Cave inhabitants were hunting or butchering bison. The chronological position of this animal is obviously of great interest, but unfortunately, we cannot rely on stratigraphic association to provide an indication of age. Therefore a section of bone, approximately $1 \mathrm{~cm} \times 3 \mathrm{~cm}$, was removed from the distal, posterior medial surface. The location for bone removal was chosen to minimize damage to the bone and to avoid areas containing measurement landmarks, in case the bone is subjected to future study. The section was submitted to Beta Analytic, Inc., for AMS dating of the collagen fraction. An age determination was returned of $1455 \pm 45 \mathrm{BP}$. The calibrated age of the sample indicates that the bison died between AD 1420 and 1490 (calibrated at $2 \sigma$ with INTCAL04 [Reimer et al., 2004]). This confirms a Mississippian association for the animal and represents an early date for this species in the Middle Tennessee region. This determination does not overlap with the earlier ages for supposedly associated charcoal discussed above (Table 2).

Teeth and several mandible fragments have been identified as elk (Cervus elaphus). These also come from Units $106 \mathrm{~N}$ and $108 \mathrm{~N}$, although MNI still is 1 . In contrast to the bison, the elk mandible fragments do show cut marks, suggesting human utilization of this large artiodactyl. There are also remains of the left humerus from a large black bear (Ursus americanus) from Unit $108 \mathrm{~N}$ that show evidence of rodent gnawing, indicating that it was exposed for some time prior to burial. Chronological control for the elk and bear is lacking, and their ages remain to be determined. 


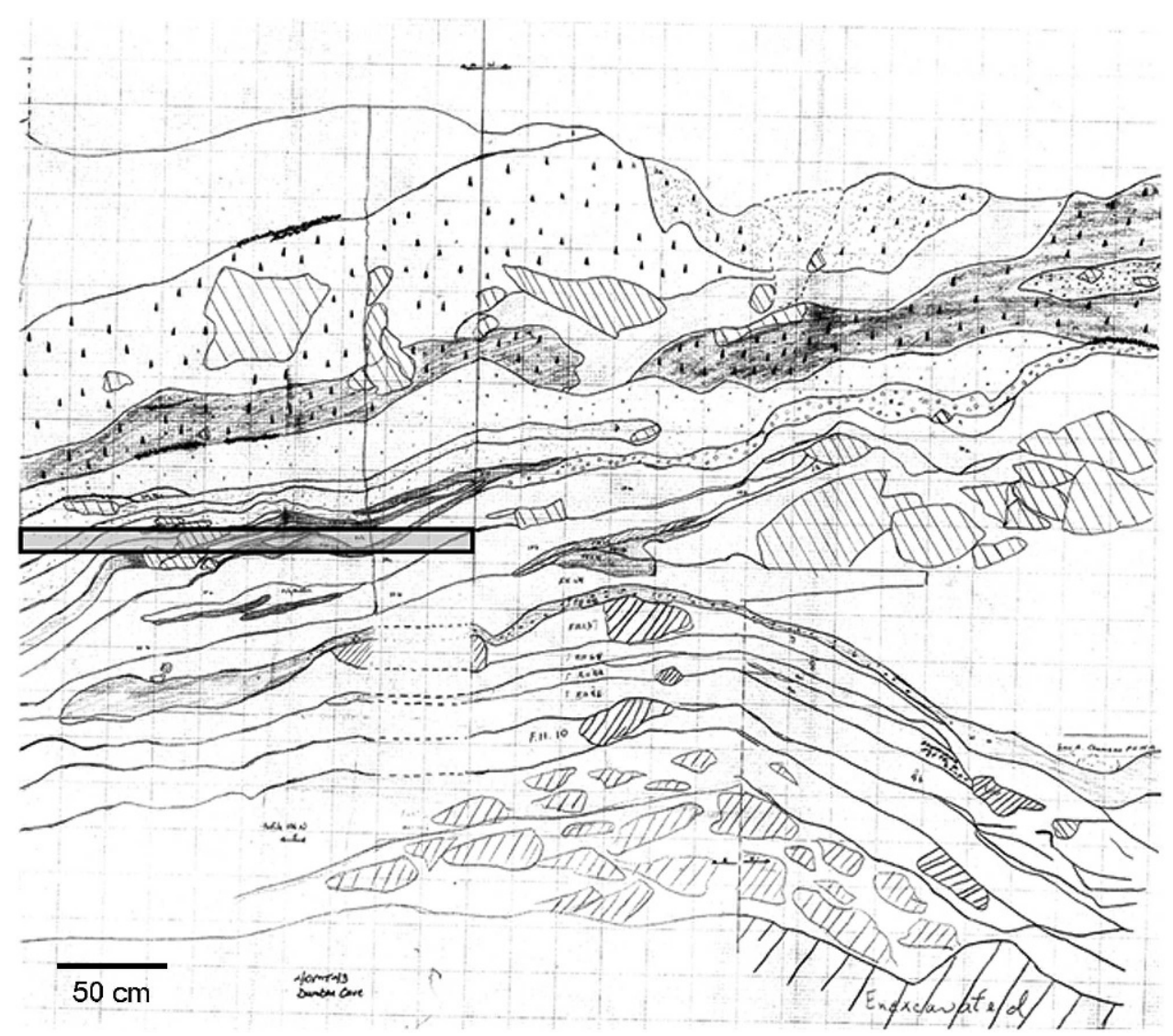

Figure 9. Profile of 1978 excavation trench at Unit $106 \mathrm{~N}$, after 1978 field notes by Pace and others. Shaded area shows single $2 \mathrm{~m} \times 10 \mathrm{~cm}$ horizontal excavation spit containing seventeen strata.

\section{Recent Archaeological Work}

At the time the prehistoric art in Dunbar Cave was discovered, the cave was protected with an old gate that could easily be breeched. In July of 2006, a team of TDEC personnel and volunteers led by independent conservationist and gate-builder Kristen Bobo installed a new, more substantial, and bat-friendly gate. Once it was well-defended, the prehistoric cave art in Dunbar Cave was announced with a public ceremony at the cave. Dunbar Cave is the first Tennessee, indeed first North American, dark-zone cave-art site open to the interested public, and the cave art is part of the interpretive program offered to visitors. The bat-friendly gate has had the intended consequence of encouraging new bat habitation. Unfortunately, white nose syndrome was recognized among the Dunbar Cave bat population in March 2010, and the cave was closed to all traffic.

In May of 2007, as Dunbar Cave State Natural Area prepared interpretive exhibits, we undertook small-scale test excavations in the glyph chamber of the cave. Two $1 \times$ $0.5 \mathrm{~m}$ units were excavated in the Ballroom, one near the warrior image and at the spot where a Late Archaic (i.e., Ledbetter) projectile point had been found just below the surface near the cave wall (Fig. 11a), and the other in seemingly intact deposits at the opposite wall of the chamber. These units at the edges of the room were chosen because the deposits in the center had been substantially modified by construction of a visitor pathway. Stratigraphy in the two room-edge units was essentially the same:

Level 1 ( 8 to $10 \mathrm{~cm}$ thick): Banded dark and light fine water-laid silts, contains historic artifacts (wood, glass, nails), heavily trampled.

Level 2 ( 1 to $2 \mathrm{~cm}$ ): Solid travertine floor over entire unit composed of banded layers of calcium carbonate, archaeologically sterile.

Level $3(10$ to $50+\mathrm{cm})$ : Homogeneous dark reddish brown sandy silt with occasional plaquettes and blocks, archaeologically sterile.

Interestingly, very few prehistoric artifacts were uncovered during these test excavations, despite the use of quarter-inch mesh to screen all sediments, but those that were found are relatively large and are made of highquality chert. They include the stemmed point shown in Figure 11a and the biface fragment shown in Figure 11b. In every case, these artifacts were lying directly in contact with the top of Level 2, the travertine surface.

In May 2008, the state installed three interpretive panels in front of the principal glyph walls in the Ballroom, each 

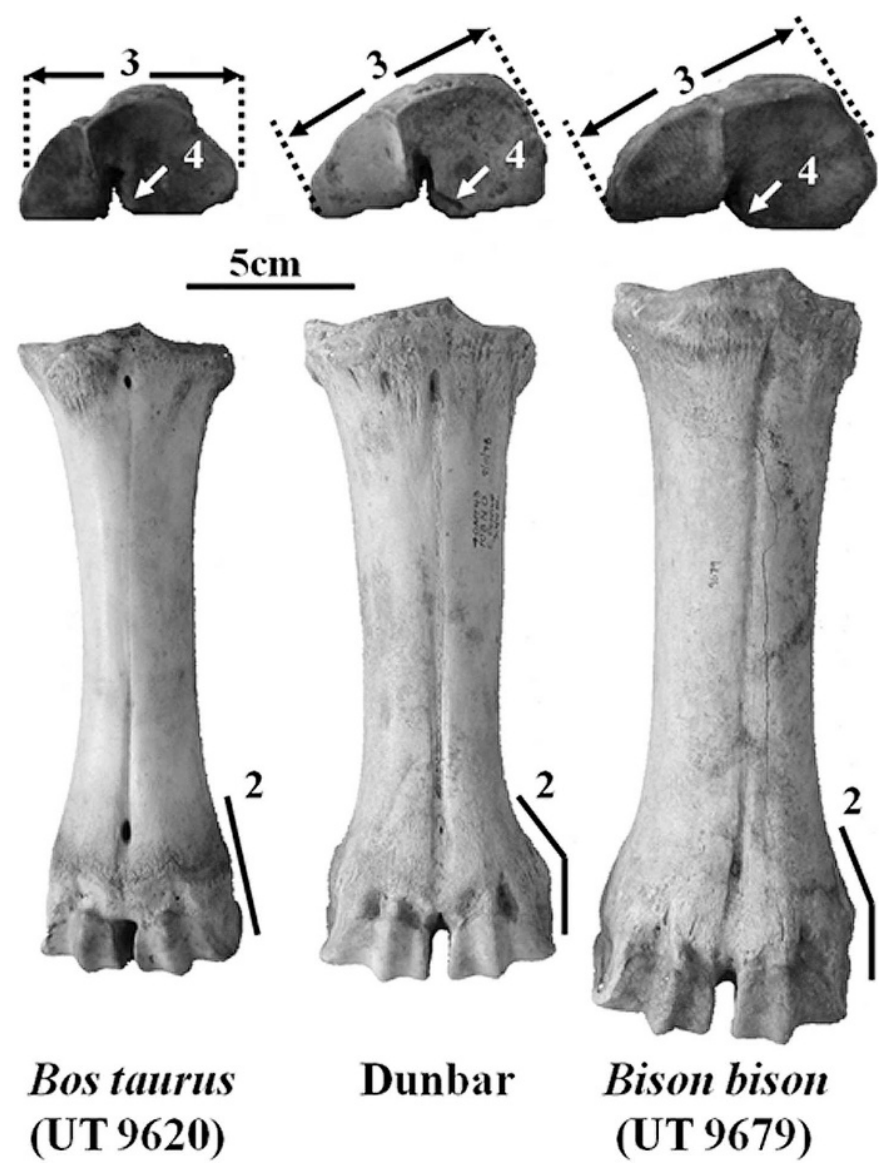

Bison bison (UT 9679)

Figure 10. Comparison of Dunbar Cave bison metacarpal to modern bison and cow.

supported by two posts buried in the cave sediments. We were asked to excavate the holes for the support legs, in effect, providing six more shovel tests in the area of the main glyph concentrations. Each of these units was $20 \mathrm{~cm}$ square and excavated to a depth of about $50 \mathrm{~cm}$ where possible. In two cases, rocks were encountered at more than $30 \mathrm{~cm}$ below the surface. With one exception, all six shovel tests displayed the same stratigraphy as the test units described earlier, although in the northernmost test unit, closest to the warrior panel, a somewhat more complex sequence was encountered in and below Level 3. We briefly describe that profile as representative of all six 2008 units. At the top, $10 \mathrm{~cm}$ of banded dark and light fine water-laid sediments was encountered, Level 1 as defined in 2007. In all six units, a layer corresponding to Level 2, the travertine surface, was identified next, although in four units Level 2 was decomposed, reflected by travertine clasts and calcite sand. Level 2 varied from 1 to $3 \mathrm{~cm}$ in thickness. Level 3, $20 \mathrm{~cm}$ thick, consisted of dark, reddish-brown sandy loam with occasional lenses of silt and clay. Level 4 , an $8 \mathrm{~cm}$ layer of plaquettes rich in calcite, and Level 5, lightcolored, cross-bedded silts and sands, decends $50 \mathrm{~cm}$ from the base of Level 4. Only two artifacts were encountered during excavation of the six postholes: a white historic ceramic shard at the top of Level 1, and a large chert core (Fig. 11c) lying on the travertine surface at the contact between Levels 1 and 2 .

Even the limited information these excavations provide concerning prehistoric use of the interior of Dunbar Cave is intriguing. It seems that there was, at some time in the past, a travertine surface that extended across the Ballroom not unlike those present today in other parts of the cave, including the nearby Counterfeiter's Room. That surface, as elsewhere, probably held water and may have been composed of gours or other water-related speleothems. All of the excavated prehistoric artifacts are Late Archaic in aspect and lay directly on the surface of that submerged floor. Recall also that the single ${ }^{14} \mathrm{C}$ age determination from this room is Late Archaic. We speculate that these artifacts were intentionally deposited, "offered" into the waters of the Ballroom some 4000 years ago by Archaic period visitors, long before the artwork was added to the walls. Such practices are well known in Mesoamerica, where rituals and offerings were commonly made in caves, as has been demonstrated both ethnographically and archaeologically (see papers in Brady and Prufer, 2005). Such a practice would explain at least some evidence for Archaic cave use in the Southeast as well (Simek and Cressler, 2009; Simek et al., 1998; Crothers et al., 2002).

\section{Conclusions}

Dunbar Cave is a remarkable prehistoric site, not just for Tennessee but for the entire Eastern Woodlands. Human use of the cave interior spans at least 4000 years. People were interred in the cave, cave minerals may have been procured, and the cave interior was extensively explored. A prehistoric sanctuary was created during the Mississippian period (around AD 1300) with dark zone, parietal cave art depicting various iconographic images, including heroic characters from cosmological narratives. It is even possible that Archaic visitors (about 2000 BC) expressed their reverence for the underworld by leaving large, finely-worked stone tools in pools in the cave interior. Outside the cave, the vestibule rockshelter was periodically occupied beginning late in the Pleistocene and continuing through all Holocene prehistoric phases in the Southeast, with both hunting and agricultural peoples repeatedly visiting the site to hunt its surrounds, to obtain stone for their tools, to bury their dead, and to carry out religious rituals.

Archaeological work at Dunbar Cave will continue, and there are a number of aspects yet to be examined. For example, a visit to the hilltop crowning Dunbar Cave in 2007 revealed that in many places the rocky outcrops have been excavated, and in those areas large and fine-grained chert nodules were apparent, some tested with hammerstone blows. The staff of Dunbar Cave was aware of some of these, but in a short period of time we identified at least a half-dozen major chert quarry sites outside the cave. 


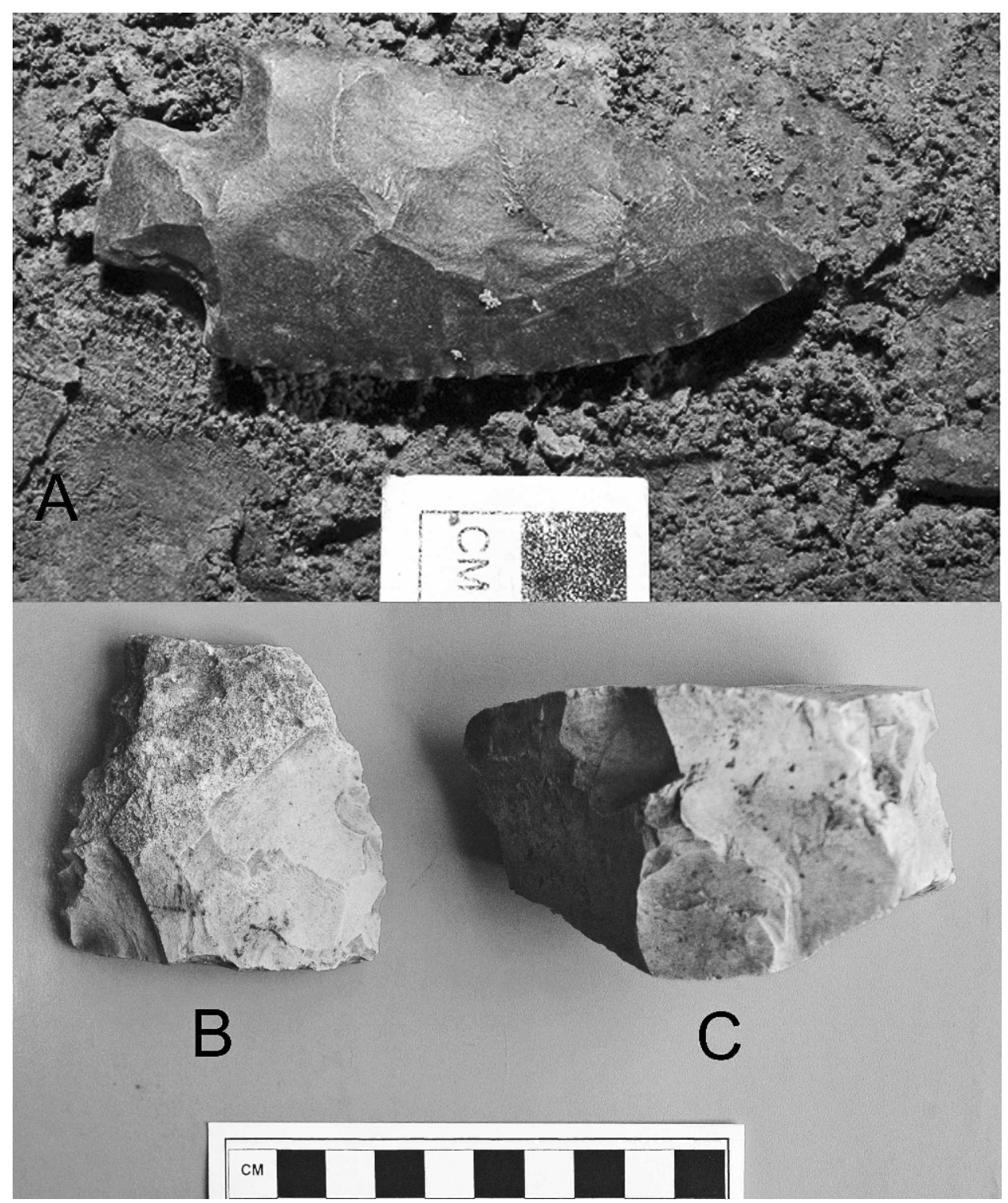

Figure 11. Artifacts recovered on the surface of buried speleothem floor in the Ballroom of Dunbar Cave. A. Late Archaic (Ledbetter type) projectile point. B. Biface fragment found in test excavation. C. Core fragment found in posthole excavation.

Some of these are quite extensive, and in some places numerous chert nodules derived from the outcrops are piled in association with knapping debris. The vicinity of Dunbar Cave was probably a significant prehistoric chert mine located near the renowned Dover, Tennessee, chert quarries. In 2006, we visited a part of the cave interior we had never seen and observed several localities where gypsum crusts had been battered from the cave walls and removed. A hammerstone lay on the floor at the base of one of these walls. It may be that prehistoric miners were active both inside and outside Dunbar Cave, as they were in several Tennessee sites. We have yet to undertake intensive work on these discoveries.

There is, thus, a great deal of research yet to do at Dunbar Cave. The cave has more than eight miles of mapped passages, but we have visited less than a quarter of that length. There is an internal archaeological survey to carry out, seeking and documenting art and other activities like mining and burial that might have taken place in the cave's recesses. Chert mining outside the cave should also be examined in detail, and the considerable remaining vestibule sediments warrant further investigation. Dunbar Cave is a remarkable archaeological resource. It deserves and will receive the attention required by its complex, multifaceted and long-term prehistoric use.

\section{ACKNOWLEDGEMENTS}

The authors thank the staff of Dunbar Cave State Natural Area, especially Superintendent Bob Wells. The 
Friends of Dunbar Cave and the entire community of Clarksville have been very supportive of archaeological research at the cave. Jerry Clark, who discovered several of the glyphs, and Ronnie Hunter deserve special thanks. Sarah C. Sherwood (Sewanee, the University of the South) helped us during the 2007 test excavations and advised Heather Welborn on her stratigraphic research in the site. Tennessee State Archaeologists Nick Fielder and Mike Moore provided us permits to do the work, and made the 1977-78 collections available to us. Bill Lawrence and John Froeschauer, archaeologists with the Tennessee State Parks, continue their great support. Stuart Carroll helped us in the gating project and was, as always, instrumental in sustaining general morale. Patty Jo Watson made substantive improvements to the presentation and greatly improved the clarity in her review of this paper; a second anonymous reviewer was also helpful. Funding for the research described here came from the National Science Foundation, the University of Tennessee, and anonymous donors to the UT Cave Archaeology Research Team.

\section{REFERENCES}

Boszhardt, R.F., 2003, Deep Cave Rock Art in the Upper Mississippi Valley: St. Paul, MI, Prairie Smoke Press, 94 p.

Brady, J.E., and Prufer, K.M., 2005, In the Maw of the Earth Monster: Studies of Mesoamerican Ritual Cave Use: Austin, University of Texas Press, 448 p.

Brain, J.P., and Phillips, P., 1996, Shell Gorgets: Styles of the Late Prehistoric and Protohistoric Southeast: Cambridge, Massachusetts, Peabody Museum Press, 542 p.

Brown, J.A., 2007, On the identity of the birdman within Mississippian period art and iconography, in Reilly III, F.K., and Garber, J.F., eds., Ancient Objects and Sacred Realms: Interpretation of Mississippian Iconography: Austin, University of Texas Press, p. 56-106.

Butler, B.M., 1977, A preliminary archaeological assessment of Dunbar Cave (40MT43): Nashville, Division of Archaeology, Tennessee Department of Conservation.

Creswell, B.A., 2007, Phase I Archaeological Survey of Caves and Rockshelters within the Proposed Corridor of the Knoxville Parkway (SR475) in Anderson, Knox, and Loudon Counties, Tennessee: Knoxville, University of Tennessee Archaeological Research Laboratories.

Crothers, G., Faulkner, C.H., Simek, J.F., Watson, P.J., and Willey, P., 2002, Woodland period cave use in the eastern woodlands, in Anderson, D.G., and Mainfort, R.C., Jr., eds., The Woodland Southeast: Tuscaloosa, University of Alabama Press, p. 502-524.

Diaz-Granados, C., and Duncan, J.R., 2000, The Petroglyphs and Pictographs of Missouri: Tuscaloosa, University of Alabama Press, $280 \mathrm{p}$.

Diaz-Granádos, C., Rowe, M.W., Hyman, M., Duncan, J.R., and Southon, J.R., 2001, AMS radiocarbon dates for charcoal from three Missouri pictographs and their associated iconography: American Antiquity, v. 66, p. 481-492.

Faulkner, C.H., ed., 1986, The Prehistoric Native American Art of Mud Glyph Cave: Knoxville, University of Tennessee Press, 124 p.

Faulkner, C.H., 1988, A study of seven southeastern glyph caves: North American Archaeologist, v. 9, no. 3, p. 223-246.

Faulkner, C.H., Deane, B., and Earnest, H.H., Jr., 1984, A Mississippian period ritual cave in Tennessee: American Antiquity, v. 49, no. 2, p. $350-361$.
Faulkner, C.H., and Simek, J.F., 1996, Mud glyphs: Recently discovered cave art in eastern North America: International Newsletter on Rock Art, v. 15 , p. $8-13$.

Hall, R.L., 1997, An Archaeology of the Soul: North American Indian Belief and Ritual: Champaign, University of Illinois Press, 222 p.

Holmes, W.H., 1883, Art in shell of the ancient Americans, in 2nd Annual Report of the Bureau of American Ethnology, 1879-80: Washington, D.C., Government Printing Office, p. 179-305.

Leroi-Gourhan, A., 1971, Préhistoire de l'Art Occidental, second edition: Paris, Mazenod, 499 p.

Lewis, T.M.N., and Lewis, M.D.K., 1995, The Prehistory of the Chickamauga Basin in Tennessee: Knoxville, University of Tennessee Press, two vols., 683 p.

Matthews, L.E., 2005, Dunbar Cave: The Showplace of the South: Huntsville, Alabama, National Speleological Society, $145 \mathrm{p}$.

Muller, J., 1989, The southern cult, in Galloway, P.K., ed., The Southeastern Ceremonial Complex: Artifacts and Analysis: Lincoln, University of Nebraska Press, p. 11-26.

Pace, R.A., and Hood, V.P., 1978, Archaeological Investigations at Dunbar Cave: A Stratified Rockshelter: Nashville, Division of Archaeology, Tennessee Department of Conservation.

Reimer, P.J., et al., 2004, IntCal04 terrestrial radiocarbon age calibration, 0-26 cal kyr BP: Radiocarbon, v. 46, no. 3, p. 1029-1058.

Sabo III, G., 2008, Rock art and the study of ancient religions in southeastern North America, in Fogelin, L., ed., Religion, Archaeology, and the Material World: Carbondale, Center for Archaeological Investigations, Southern Illinois University, occasional paper 36, p. 279-296.

Simek, J.F., 2010, Afterword: Onward into the darkness (still following the light of Pat Watson's lamp, of course), in Dye, D., ed., Cave Archaeology in the Eastern Woodlands: Essays in Honor of Patty Jo Watson: Knoxville, University of Tennessee Press, p. 261-270.

Simek, J.F., Blankenship, S., Herrmann, N., Sherwood, S.C., and Cressler, A., 2010, New cave and rock art sites in Tennessee: 2007, in Baumann, T., and Groover, M., eds., Pottery, Passages, Postholes, and Porcelain: Essays in Honor of Charles H. Faulkner: Knoxville, McClung Museum, Report of Investigations series, University of Tennessee, p. 71-88.

Simek, J.F., and Cressler, A., 2001, Issues in the study of prehistoric southeastern cave art: Midcontinental Journal of Archaeology, v. 26, no. 2, p. 233-250.

Simek, J.F., and Cressler, A., 2005, Images in darkness: Prehistoric cave art in southeastern North America, in Loendorf, L., Chippendale, C., and Whitley, D., eds., Discovering North American Rock Art: Tucson, University of Arizona Press, p. 93-113.

Simek, J.F., and Cressler, A., 2009, Prehistoric cave art in southeastern North America, in White, W.B., ed., Proceedings of the 15th International Congress of Speleology: Huntsville, Alabama, National Speleological Society, p. 135-139.

Simek, J.F., Douglas, J.C., and Wallace, A., 2007, Ancient cave art at Dunbar Cave State Natural Area: Tennessee Conservationist, v. 23, no. 5 , p. $24-26$.

Simek, J.F., Franklin, J.D., and Sherwood, S.C., 1998, The context of early southeastern prehistoric cave art: A report on the archaeology of 3rd Unnamed Cave: American Antiquity, v. 63, no. 4, p. 663-675.

Van West, C., 1998, Dunbar Cave State Natural Area, in Van West, C., ed., Tennessee Encyclopedia of History and Culture: Nashville, Tennessee, Rutledge Hill Press, 266 p.

Wagner, M.J., 1996, Written in stone: An overview of the rock art of Illinois, in Faulkner, C.H., ed., Rock Art of the Eastern Woodlands: San Miguel, California, American Rock Art Research Association occasional paper 2, p. 47-79.

Waring, A.J., Jr., and Holder, P., 1945, A prehistoric ceremonial complex in the southeastern United States: American Anthropologist, v. 47, no. 1, p. 1-34, doi:10.1525/aa.1945.47.1.02a00020.

Whidby, J., 1999, Idaho Springs and Dunbar Cave Resort: The showplace of the south: Journal of the Cumberland Spelean Association, v. 6, no. 1 , p. $7-12$. 